\title{
DNA SEQUENCE POLYMORPHISMS IN THE GENUS SACCHAROMYCES. I. COMPARISON OF THE HIS4 AND RIBOSOMAL RNA GENES IN LAGER STRAINS, ALE STRAINS AND VARIOUS SPECIES
}

\author{
by
}

\section{MOGENS BOHL PEDERSEN}

\author{
Department of Physiology, Carlsberg Laboratory, \\ Gamle Carlsberg Vej 10, DK-2500 Copenhagen, Valby \\ and \\ Department of Brewing Chemistry, Carlsberg Research Laboratory \\ Gamle Carlsberg Vej 10, DK-2500 Copenhagen, Valby
}

Keywords: Brewers yeasts, $\alpha$-galactosidase, sporulation, restriction endonuclease patterns, molecular hybridization, S. bayanus, S. carlsbergensis, S. cerevisiae, S. diastaticus, S. ellipsoideus, S. fermentati, S. italicus, S. pastorianus

The region of chromosome XII containing the $R D N 1$ gene which encodes the cytosolic ribosomal RNA molecules and the region of chromosome III containing the HIS4 (histidine 4) gene were analysed in 30 lager yeast strains, 11 ale strains and 20 strains from a number of different species in the genus Saccharomyces.

With the aid of restriction endonuclease fragment patterns and cloned probes to the RDNI gene of S. cerevisiae three forms of this gene were identified, two of them corresponding to the previously known forms I and II and a third one characterized by an additional HindIII site located in the 3' spacer region. A more distantly related form of the $R D N /$ gene containing a single HindIII restriction site was found in Saccharomyces fermentati and one form without any HindIII site in a wild yeast contaminant.

With the help of the restriction endonuclease fragments derived from the HIS4 region seven genotypes can be recognized. They result from various combinations of three restriction endonuclease fragment patterns designated I, II and III, each pattern represents a chromosome.

All lager strains are homozygous for form II of the ribosomal RNA gene and heterozygous for patterns I and II of the HIS4 gene. An exception is one German brewing strain which is homozygous for pattern Il.

With one exception the ale strains were homozygous for form II of the RDNI gene and for pattern I of the HIS4 gene. One British strain contains form I of the RDNI gene. Bakers yeast, S. diastaticus and $\mathrm{S}$. italicus are homozygous for form I of the $R D N I$ gene and for pattern I of the HIS4 gene. In S. bayanus and S. pastorianus homozygosity for form III of the RDNI gene was combined with heterozygosity for patterns II and III of the HIS4 gene. S. uvarum is homozygous for both form III of the RDNI gene and pattern III of the HIS4 gene. Form III of the RDNI gene and patterns I and II of the HIS4 gene were combined in a Chinese brewing strain and a strain designated as a type strain of S. carlsbergensis.

The nucleotide sequence polymorphisms are useful markers for strain characterization in addition to the generally used fermentation properties.

Abbreviations: $b p=$ basepairs; $k b=$ kilobase; $\mathrm{SSC}=0.15 \mathrm{M}-\mathrm{NaCl}, 15 \mathrm{~mm}-\mathrm{Na}$ citrate; Tris - tris-(hydroxymethyl)amino methane. 


\section{INTRODUCTION}

In yeast taxonomic studies a genus or a species is usually delimited on the basis of morphology, fermentation characteristics (33), capacity of spore formation and ability to hybridize $(15,36)$. Closely related strains are distinguished from one another by individual fermentative abilities, enzyme polymorphisms $(8,37)$ and most recently nucleic acid sequence variations $(4,12,17$, $19,20,35)$. The analysis of dissociation of DNA and its reassociation with DNA or RNA has added unlimited possibilities for characterization of strains and species within as well as among genera. Low sequence homology has been established among the genera Schwanniomyces, Saccharomyces, Debaryomyces and Pichia $(1,25)$. Within the genus Saccharomyces some species show close homology (28).

In the present study two specific chromosomal regions of the Saccharomyces genomes in 30 lager strains, 11 ale strains and 20 strains from a number of different species have been characterized for polymorphisms using restriction endonuclease fragment patterns and molecular hybridization to specific probes. The first region is in chromosome XII and contains the RDNI gene encoding the cytosolic $25 \mathrm{~S}, 5.8 \mathrm{~S}, 18 \mathrm{~S}$ and $5 \mathrm{~S}$ ribosomal RNA molecules $(20,21,22)$. The $5 S$ sequence is transcribed separately from the opposite strand of the gene. In Saccharomyces cerevisiae this gene is present in over 100 tandemly repeated copies $(22,29)$. The gene is generally highly conserved in sequence and overall organization throughout the pro- and eukaryotic kingdoms $(6,9,32,34)$. As a probe was used the plasmid constructed by Petes, Hereford and SKRYABIN (20) which contains form II of the $R D N 1$ gene. The second region analysed contains the HIS4 gene on chromosome III which encodes three enzymatic functions in the biosynthesis of histidine. The plasmid containing this gene has been constructed by HOLMBERG et al. (11) and has previously disclosed the existence of at least two homeologous chromosomes III in the Carlsberg lager strain $(12,17)$. The nucleotide sequence of the HIS4 region of one of them is so different from the corresponding region in S. cerevisiae that genetic recombination is not possible between them. Extensive nucleotide sequence differences between the Carlsberg lager strain and S. cerevisiae have also been shown to exist in other portions of chromosome III (12) and in other chromosomes (35). Various Saccharomyces species have extensively diverged nucleotide sequences in the members of the $S U C$ gene family encoding invertase (4).

\section{MATERIALS AND METHODS}

\subsection{Strains and media}

The strains used in this study are listed in Tables I, II and III. Agar plates with complete medium (YPD) and plates containing sporulation medium (SPOR) were prepared according to Sherman, Fink and Hicks (30). Growth on melibiose was tested on plates of the following composition: $0.2 \%$ melibiose (Merck 12240), $0.67 \%$ yeast nitrogen base without amino acids (Bacto 919-15) and 2\% agar (Bacto 0140-01). All strains were propagated on YPD plates for DNA isolation and replicated to sporulation plates and melibiose containing plates. The plates were incubated at $22{ }^{\circ} \mathrm{C}$, the frequency of asci determined in each strain after seven days (10) and the capacity to grow on melibiose recorded. The strains were further tested for excretion of $\alpha$-galactosidase (melibiase) by growing them on plates containing $0.2 \%$ galactose (Merck 4062 ), $0.67 \%$ yeast nitrogen base without amino acids (Bacto 919-15) and 2\% agar for one or two days. Thereafter the colonies were covered with a layer of agar ( $5 \mathrm{ml}$ ) containing $1.5 \%$ agar, $31 \mathrm{~mm}$-citric acid, $39 \mathrm{~mm}-\mathrm{KH}_{2} \mathrm{PO}_{4}, \mathrm{pH} 4.0$ according to the procedure of BuCKHOLZ and ADAMS (2). Instead of using $p$-nitrophenyl- $\alpha$-D-galactoside as the indicator in the overlayer, $40 \mu$ mole $\cdot \mathrm{ml}^{-1}$ 4-methyl-umbelliferyl- $\alpha$-D-galactoside (Sigma M-7633 USA) was included. Melibiase will produce free 4-methyl-umbelliferone which can be detected by its fluorescence (B.S. ENEVOLDSEN, pers. comm., 27). Detection of the fluorescing compound is possible after 5-40 min incubation of the plates at room temperature.

\subsection{Preparation of DNA}

DNA from the yeast cells was isolated by a modification of the method of CAMERON, PHILIPPSEN and DAvis (3). Yeast cells were scraped from a YPD plate which previously had been incubated for 48 hours, suspended in $5 \mathrm{ml}$ of 20 
Table I.

Characteristics of lager yeast strains (Saccharomyces carlsbergensis). RDN1: Restriction endonuclease fragment pattern (cf. Fig. 9) of the RDN1 gene encoding the cytosolic ribosomal RNA molecules. HIS4: Restriction endonuclease pattern (cf. Fig. 9) of the HIS4 region in chromosome III. Spor: sporulation, Mel: capacity to grow on melibiose minimal medium, M.ase: Excretion of melibiase. $-/+$ : Indicates colonies of both types. $n . d .:$ not determined. (-): Very poor growth on melibiose minimal medium.

\begin{tabular}{lcccccl}
\hline Strain number & RDNI & HIS4 & Spor\% & Mel & M.ase & Source \\
\hline BK1100 & II & I + II & $<1$ & + & + & Denmark, Tuborg, 1945 \\
BK1101 & II & II & $<1$ & + & + & Germany, Pschorr, 1939 \\
BK1103 & II & I + II & 1 & + & + & Denmark, Carlsberg, 1964 \\
BK1111 & II & I + II & $<1$ & + & + & Germany, Weihenstephan, 1966 \\
BK1112 & II & I + II & $<1$ & + & + & Denmark, Alfr. Jørgensen no. 2190 \\
BK1115 & II & I + II & $<1$ & + & + & USA, Schaefers, New York, Belgian yeast, 1947 \\
BK1116 & II & I + II & $<1$ & + & + & Germany, Dortmunder Union, 1936 \\
BK2224 & II & I + II & $<1$ & + & + & Germany, Kindl Berlin, 1950 \\
BK2229 & II & I + II & $<1$ & + & + & Denmark, Alfr. Jørgensen no. 1522 \\
BK2231 & II & I + II & $<1$ & + & + & Sweden, Lyckholm, Gothenburg, 1943 \\
BK2237 & II & I + II & 15 & - - & + & Pilsen, Erste Pilsener Akt. Br., 1937 \\
BK2246 & II & I + II & 1 & + & + & Denmark, Carlsberg lager strain \\
C82-FP2 & II & I + II & 2 & + & + & Malta \\
C82-FP3 & II & I + II & 20 & + & + & Italy \\
C82-FP4 & II & I + II & 5 & + & + & Cameroun \\
C82-FP5 & II & I + II & 12 & + & + & Norway \\
C82-FP6 & II & I + II & 3 & + & + & France \\
C82-FP7 & II & I + II & 24 & + & + & Portugal \\
C82-FP8 & II & I + II & 11 & + & + & Portugal \\
C82-FP9 & II & I + II & 20 & + & + & Canada \\
C82-FP11 & II & I + II & $<1$ & - & + & Norway \\
C82-FP13 & II & I + II & n.d. & - & + & Portugal \\
C82-FP14 & II & I + II & 6 & - & + & Portugal \\
C82-FP18 & II & I + II & 7 & + & + & Great Britain \\
C82-FP19 & II & I + II & 9 & + & + & Cameroun \\
C82-FP20 & II & I + II & 10 & + & + & Cameroun \\
C82-FP21 & II & I + II & 38 & + & - & Portugal \\
C82-FP22 & II & I + II & 20 & $-/+$ & $-/+$ & Sweden \\
C82-FP26 & II & I + II & 41 & + & + & Great Britain \\
C82-FP32 & II & I + II & 6 & + & + & Finland \\
\hline & & & & & &
\end{tabular}

mM-dithiothreitol (Sigma D-0632 USA) and incubated at $30^{\circ} \mathrm{C}$ for $30-45 \mathrm{~min}$. Then zymolyase60000 (from Arthrobacter luteus, Seikagaku Kogyo Co. Ltd., Japan) was added (1.4 mg). The solution was further incubated at $30^{\circ} \mathrm{C}$ for 30 $\mathrm{min}$. Cell lysis was induced by addition of $0.2 \mathrm{ml}$ $10 \%$ sodium dodecyl sulfate ( $\mathrm{SDS}$ ), $0.5 \mathrm{ml}$ of 0.5 M-EDTA ( $\mathrm{pH} 8.5$ ) and $0.5 \mathrm{ml} 2 \mathrm{M}$-Tris base (tris(hydroxymethyl)-amino methane). After stirring the solution was heated to $65^{\circ} \mathrm{C}$ for $30 \mathrm{~min}$. The tube was then cooled on ice and one $\mathrm{ml}$ of 5 M-potassium acetate was added. After one hour on ice the tube was spun for $10-15 \mathrm{~min}$ at $4000 \mathrm{~g}$ and the nucleic acids in the supernatant were precipitated in $70 \%$ ethanol. After one hour at $-20{ }^{\circ} \mathrm{C}$ the precipitate was spun down at $4000 \mathrm{~g}$ for $10 \mathrm{~min}$, resuspended in $10 \mathrm{mM}$-Tris, $1 \mathrm{~mm}$ EDTA buffer ( $\mathrm{pH} 7.5$ ) and $2.5 \mu \mathrm{g}$ ribonuclease $\mathrm{A}$ (Sigma R-5125) as well as 40 units of ribonuclease $T_{1}$ (Sigma R-8251 USA) were added. The ribonuclease treatment was performed for 30-45 $\mathrm{min}$ at room temperature.

After the ribonuclease treatment one volume of phenol (equilibrated with Tris-EDTA buffer) was added. The phenol treatment was performed twice and the aqueous phase was washed three 
Table II.

Characteristics of ale strains (Saccharomyces cerevisiae). RDN1: Restriction endonuclease fragment pattern (cf. Fig. 9) of the RDN1 gene encoding the cytosolic ribosomal RNA molecules. HIS4: Restriction endonuclease fragment pattern (cf. Fig. 9) of the HIS4 region in chromosome III. Spor: Sporulation. Mel: Capacity to grow on melibiose minimal medium. M.ase: Excretion of melibiase. -/+: Colonies of both types.

\begin{tabular}{lcrrrll}
\hline Strain number & RDNI & HIS4 & Spor\% & Mel & M.ase & Source \\
\hline BK3300 & II & I & $<1$ & - & - & Denmark, Ceres 1920 \\
BK3302 & II & I & 1 & - & - & Denmark, Horsens 1932 \\
BK3304 & II & I & $<1$ & - & - & Great Britain, Whitbread, London 1937 \\
BK3313 & II & I & 5 & - & - & Sweden, Stockholms Bryggerier, Clo 5 1949 \\
BK3331 & I & I & 50 & - & - & Great Britain, St. Austel Brewery \\
C82-FP10 & II & I & $<1$ & - & - & Canada \\
C82-FP15 & II & I & $>90$ & - & - & Great Britain \\
C82-FP16 & II & I & 59 & - & - & Great Britain \\
C82-FP17 & II & I & 8 & - & - & Great Britain \\
C82-FP23 & II & I + II & $1-20$ & $-/+$ & $-/+$ & Sweden \\
C82-FP25 & II & I + II & 20 & $-/+$ & $-/+$ & Great Britain \\
\hline
\end{tabular}

Table III.

Characteristics of type strains and other strains for various species of Saccharomyces. RDN1: Restriction endonuclease fragment pattern (cf. Fig. 9) of the RDN1 gene encoding the cytosolic ribosomal RNA molecules. HIS4: Restriction endonuclease pattern (cf. Fig. 9) of the HIS4 region in chromosome III. Spor: Sporulation. Mel.: Capacity to grow on melibiose minimal medium. M.ase.: Excretion of melibiase. n.d.: not determined. 0: No hybridization.

\begin{tabular}{lrrccll}
\hline Strain number & RDNI & HIS4 & Spor\% & Mel & M.ase & Source \\
\hline BK4410 & I & I & 50 & - & - & S. odessa (S. cerevisiae) Baarn 1950 \\
BK4411 & III & II+III & 37 & - & - & S. bayanus Baarn \\
BK4428 & I & I & 39 & - & - & S. diastaticus NCYC 447, 1969 \\
BK4433 & III & I + II & 3 & + & + & S. (carlsbergensis) NCYC 396 \\
BK4435 & I & I & 20 & - & - & S. cerevisiae var. ellipsoideus NCYC 93 \\
BK4436 & different $R D N I$ & 0 & n.d. & - & - & S. fermentati NCYC 161 \\
BK4439 & I & I & 6 & - & - & S. italicus (syn. S. steineri) NCYC 406 \\
BK4479 & I & I & 40 & - & - & S. ellipsoideus \\
BK4505 & III & II + III & 60 & - & - & S. bayanus NCYC 374 \\
BK4515 & III & I + II & 12 & + & + & S. spec., China, brewing strain \\
BK4516 & III & II + III & 80 & - & - & S. pastorianus NCYC 392 \\
BK4525 & n.d. & I & n.d. & n.d. & n.d. & S. spec., wine yeast strain \\
BK4526 & n.d. & I & n.d. & n.d. & n.d. & S. spec., wine yeast strain \\
C81-1471 & I & I & 43 & - & - & S. spec., wild yeast, beer contaminant \\
C81-1483 & I & I & $>90$ & - & - & S. cerevisiae, bakers yeast \\
C81-1510 & III & IIIa & $<1$ & + & + & S. uvarum CBS 395., P. PHILIPPSEN \\
C81-1511 & III & III & 4 & + & + & S. uvarum R.DAVIS, P.PHILIPPSEN \\
C81-1537 & I & I & 3 & - & - & S. spec., Belgium, brewing strain \\
C82-CG625 & n.d & I + II & n.d. & n.d. & n.d. & C. GJERMANSEN \\
C82-FP33 & different $R D N 1 ~ 0$ & n.d. & n.d. & n.d. & This study \\
\hline
\end{tabular}

times with one volume of water saturated ether. After removal of the ether $1 / 10$ volume $5 \mathrm{M}$-sodium acetate and $96 \%$ ethanol were added to a final concentration of $70 \%$ ethanol. After one hour at $-20{ }^{\circ} \mathrm{C}$ the precipitated DNA was spun down and resuspended in Tris-EDTA.

Plasmid DNAs were prepared and isolated in preparative scale according to HOLMES and Quigley (13). 


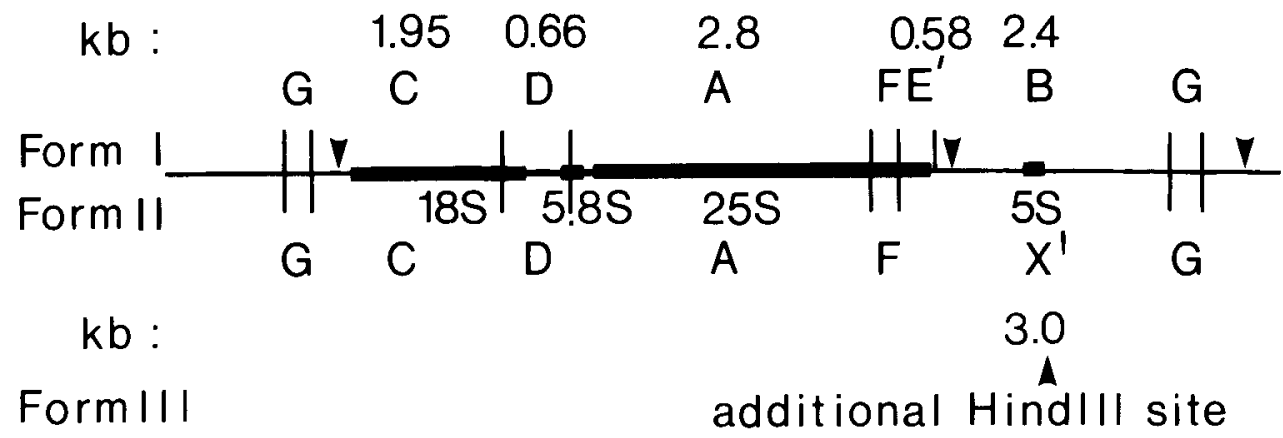

(B)

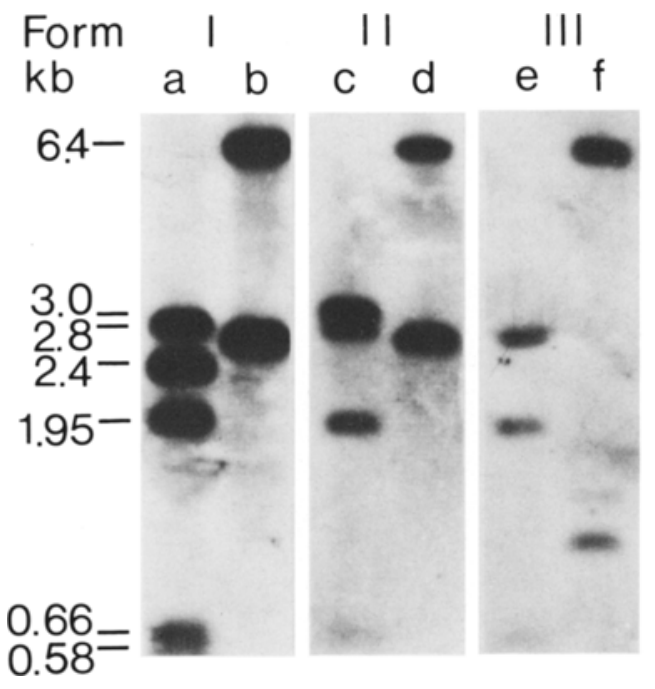

Figure 1. A: EcoRI restriction site maps (vertical bars) of the forms I and II of the RDNI gene according to PETES et al. (21). Also indicated are the HindIII sites (arrowheads). B: Autoradiograph of restriction endonuclease fragments separated by gel electrophoresis, transferred to a filter and hybridized to the radioactively labelled $R D N 1$ gene containing plasmid. The DNA under I was isolated from S. ellipsoideus BK4479, that under II from the Carlsberg lager strain BK2246 and that under III from S. bayanus BK4411. The DNA of the respective strains has been subjected to either EcoRI digestion (lanes a, $c$ and e) or to HindIII digestion (lanes $b, d$ and $f$ ). About $2 \mu \mathrm{g}$ of DNA has been loaded in each slot. Plasmid pY $1 \mathrm{rAl} 2$ was labelled with $10^{8} \mathrm{cpm}\left[\mathrm{x}_{-3}^{-32 \mathrm{P}]} \mathrm{dATP} \cdot \mu \mathrm{g}^{-1}\right.$ of DNA. Molecular hybridization and washing of the filter was performed at $60{ }^{\circ} \mathrm{C}$ with $3 \times \mathrm{SSC}$. Form $\mathrm{I}$ is cut into seven EcoRI fragments of which five, namely $\mathrm{A}, \mathrm{B}, \mathrm{C}, \mathrm{D}$ and $\mathrm{E}$, are seen in lane a. Form II is cut into six fragments of which four $\left(X^{\prime}=B+E, A, C\right.$ and $\left.D\right)$ are seen in lane c. Form III contains a double band of 2.8-2.9 kb representing fragment $\mathrm{A}$ and a fragment derived from $\mathrm{X}$ ' possibly by a deletion. It also contains bands corresponding to fragments $\mathrm{C}$ $(1.95 \mathrm{~kb})$ and $\mathrm{D}(0.66 \mathrm{~kb})$. HindIII cuts the $R D N /$ gene of forms I and II (lanes $\mathrm{b}$ and d) into two fragments with sizes of $6.4 \mathrm{~kb}$ and $2.6 \mathrm{~kb}$. Form III has an additional HindIII site which generates two fragments of $1.45 \mathrm{~kb}$ and $1.15 \mathrm{~kb}$ from the $2.6 \mathrm{~kb}$ fragment of forms I and II (lane $\mathrm{f}$ ).

\subsection{Molecular hybridization analysis}

Restriction endonucleases EcoRI, HindIII, PstI, PvulI and Sall were obtained from Boehringer Mannheim and used according to Maniatis, Fritsch and Sambrook (16). DNA fragments were separated electrophoretically in $0.7 \%$ agarose (Sigma A-6877 USA) at 1.25 $\mathrm{V} \cdot \mathrm{cm}^{-1}$ for $14-16$ hours. The gels were stained with ethidium bromide (Sigma E-8751) (1 $\mu \mathrm{g} \cdot \mathrm{ml}^{-1}$ ) in 1 litre of gelbuffer (Tris $10.8 \mathrm{~g}$, disodium EDTA $0.93 \mathrm{~g}$ and boric acid $5.5 \mathrm{~g}$, pH 8.3) (18) and photographed in UV-light. Transfer of the DNA fragments from the agarose gel was done either to a nitrocellulose filter (Millipore HAWP 000 10) or to GENESCREEN (New England Nuclear) by the method of SOUTHERN (31), but with the modification that transfer of DNA to GENESCREEN was performed in low salt 


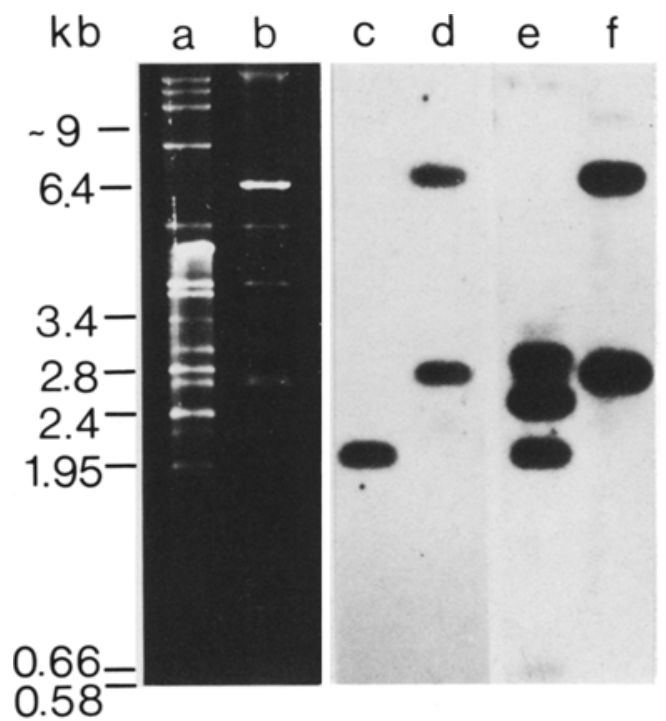

S.diastaticus

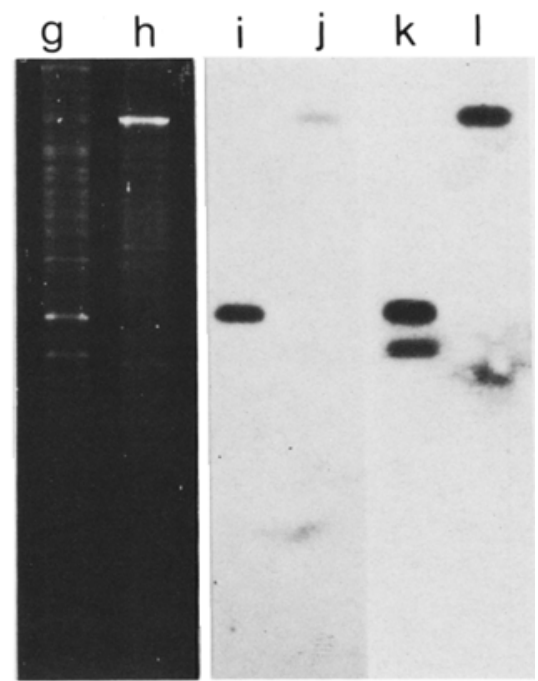

S. fermentati

\begin{tabular}{llccc}
\hline Lane & $\begin{array}{l}\text { Restriction } \\
\text { endonuclease }\end{array}$ & RDNI probe & rDNA bands $(\mathrm{kb})$ & Form \\
\hline $\mathbf{a}$ & EcoRI & - & $2.8,2.4,1.95$ & I \\
$\mathbf{b}$ & HindIII & - & $6.4,2.6$ & $"$ \\
$\mathbf{c}$ & EcoRI & "18S"pY1rA12 & 1.95 & $"$ \\
$\mathbf{d}$ & HindIII & "18S"pY1rA12 & $6.4,2.6$ & $"$ \\
$\mathbf{e}$ & EcoRI & pY1rA12 & $2.8,2.4,1.95,0.66,0.58$ & \\
$\mathbf{f}$ & HindII & pY1rA12 & $6.4,2.6$ & \\
$\mathbf{g}$ & EcoRI & - & $3.4,2.8$ & \\
$\mathbf{h}$ & HindII & - & $8.5-9$ & \\
$\mathbf{i}$ & EcoRI & "18S"pY1rA12 & 3.4 & \\
$\mathbf{j}$ & HindIII & "18S"pY1rA12 & $8.5-9$ & \\
$\mathbf{k}$ & EcoRI & pY1rA12 & $3.4,2.8$ & \\
$\mathbf{l}$ & HindIII & pY1rA12 & $8.5-9$ & \\
\hline
\end{tabular}

Figure 2. Restriction endonuclease fragment patterns of S. diastaticus NCYC 447 (lanes a to f) and S. fermentati NCYC 161 (lanes $\mathbf{g}$ to l). Lanes $\mathbf{a}, \mathbf{b}, \mathbf{g}$ and $\mathbf{h}$ present the ethidium bromide stained fragments separated by gel electrophoresis. The other lanes are hybridizations with RDNl probes according to SOUTHERN (31). Hybridization to filter bound DNA was performed at $60^{\circ} \mathrm{C}$ with $3 \times \mathrm{SSC}$.

buffer ( $1 \times \mathrm{SSC})$. Labelling of the plasmid pY1rA12 (20) carrying Form II of the RDNI gene, its derivative ("18S") (this study) and the HIS4 plasmid pC503 containing a $9.4 \mathrm{~kb}$ PstI fragment (11) with [ $\alpha{ }^{-32}$ P]dATP(NEG-012A New England Nuclear) was done by nick translation according to RigBY et al. (26) giving a specific activity in the range of $10^{7}$ to $10^{8} \mathrm{cpm} \cdot \mu \mathrm{g}^{-1}$ of plasmid DNA. For characterization of the HIS4 region and the rDNA genes by molecular hybridization the method of DENHARDT (7) with the modifications introduced by JEFFREYS and FLAVELL was used (14). The molecular hybridizations were performed in the temperature range of $58^{\circ} \mathrm{C}$ to $68^{\circ} \mathrm{C}$. Autoradiographs were obtained at $-70^{\circ} \mathrm{C}$ in Kodak X-Omatic cassettes with regular screens. 


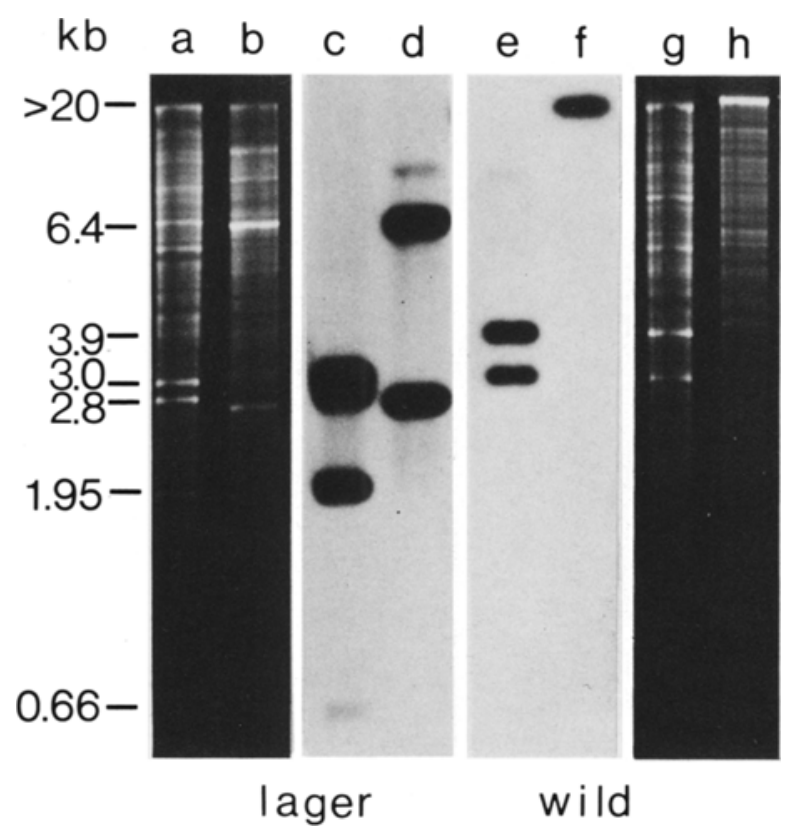

\begin{tabular}{lllcc}
\hline Lane & $\begin{array}{l}\text { Restriction } \\
\text { endonuclease }\end{array}$ & RDN1 probe & rDNA bands $(\mathrm{kb})$ & Form \\
\hline $\mathbf{a}$ & EcoRI & - & $3.0,2.8,1.95,0.66$ & II \\
$\mathbf{b}$ & HindIII & - & $6.4,2.6$ & $"$ \\
$\mathbf{c}$ & EcoRI & pYIrAI2 & $3.0,2.8,1.95,0.66$ & $"$ \\
$\mathbf{d}$ & HindIII & pY1rA12 & $6.4,2.6$ & \\
$\mathbf{e}$ & EcoRI & pYIrAI2 & $3.9,3.0$ & $>20$ \\
$\mathbf{f}$ & HindIII & pYlrAI2 & $3.9,3.0$ & \\
$\mathbf{g}$ & EcoRI & - & $>20$ & \\
$\mathbf{h}$ & HindIII & - & & \\
\hline
\end{tabular}

Figure 3. Identification of a wild yeast with the aid of the $R D N /$ gene. Lanes a to $d$ are from the Carlsberg lager strain while lanes $e$ to $h$ are from the contaminant C82-FP33 in the brewing yeast. Hybridization to filter bound DNA and washing was performed at $60^{\circ} \mathrm{C}$ with $3 \times S S C$.

\section{RESULTS}

\subsection{Physiological characteristics of the}

\section{Saccharomyces strains analysed}

In Tables I, II and III are given for each strain the capacity to sporulate, to grow on melibiose minimal medium and to excrete the enzyme melibiase. In Table I are grouped the lager strains (S. carlsbergensis), in Table II the ale strains (S. cerevisiae) and in Table III various other yeast strains including Saccharomyces type strains obtained from different culture collections. The lager strains (Table I) tend to be poor sporulators. (Here tested at $22^{\circ} \mathrm{C}$.) Twenty-five of the strains could grow on melibiose and excrete melibiase. Four of the lager strains would not grow on the melibiose minimal plates but displayed detectable amounts of melibiase activity when the strains were grown on galactose for induction of the enzyme and subsequently tested with 4-methyl-umbelliferyl- $\alpha$-D-galactoside. One strain grew on melibiose but the test for enzyme excretion was negative. One sample contained a mixture of cells with a wide range of melibiose activity and a wide range of sporulation capacity.

Only one of the ale strains analysed (Table II) sporulated with a high frequency at $22^{\circ} \mathrm{C}$. Nine of the strains were unable to grow on melibiose and excrete melibiase. Two of the samples contained a mixture of cells with a wide range of melibiase activity and capacity to grow on 


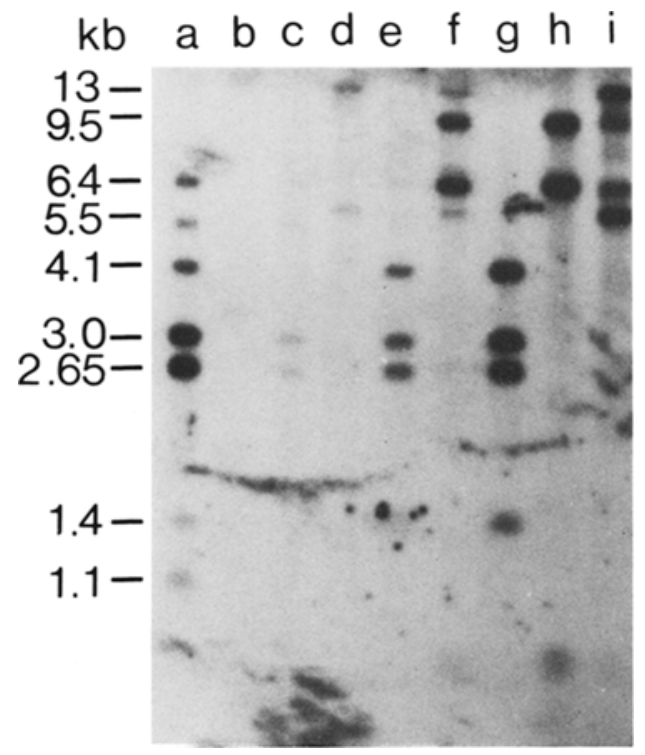

\begin{tabular}{lllll}
\hline Lane & $\begin{array}{l}\text { restriction } \\
\text { endonuclease }\end{array}$ & strain & HIS4 bands (kb) & pattern \\
\hline a & EcoRI & Carlsberg lager BK2246 & $6.2,5.0,4.1,3.0$, & I and II \\
b & & bacteriophage $\lambda$ DNA & $2.65,1.4,1.1$ & \\
c & EcoRI & German lager BKI101 & $6.2,5.0,3.0,2.65$ & II \\
d & HindIII & German lager BK1101 & $13.0,5.5$ & II \\
e & EcoRI & S.(carlsbergensis) NCYC396 & $6.2,4.1,3.0,2.65$, & I and II \\
& & & 1.4 & I and II \\
f & HindIII & S.(carlsbergensis) NCYC396 & $13.0,9.5,6.4,5.5$ & \\
& & & $0.69,0.62$ & I \\
g & EcoRI & S. italicus NCYC406 & $4.1,3.0,2.65,1.4$ & I \\
h & HindIII & S. italicus NCYC406 & $9.5,6.4,0.69,0.62$ & I and II \\
i & HindIII & Carlsberg lager BK2246 & $13.0,9.5,6.4,5.5$ & \\
& & & $0.69,0.62$ & \\
\hline
\end{tabular}

Figure 4. Autoradiograph of restriction endonuclease fragment patterns of alleles of the HIS4 region in four Saccharomyces strains. Lanes $\mathbf{a}, \mathbf{c}, \mathbf{e}$, and $\mathbf{g}$ contain EcoRI digested DNA, lanes $\mathbf{d}, \mathbf{f}, \mathbf{h}$ and $\mathbf{i}$ are loaded with HindIII digested DNAs. Molecular hybridization of the radioactively labelled HIS4 containing plasmid and washing of the filter bound DNA was performed at $60^{\circ} \mathrm{C}$ with $3 \times \mathrm{SSC} .1 \mu \mathrm{g}$ of the plasmid DNA was labelled with $10^{8} \mathrm{cpm}\left[x^{-32} \mathrm{P}\right]$ dATP.

melibiose, but only one of these revealed a similar variability in sporulation frequency.

A wide range of sporulation frequencies at 22 ${ }^{\circ} \mathrm{C}$ was observed among the various species and type strains studied (Table III). Four accessions could ferment melibiose and excrete melibiase. These were the two strains of S. uvarum, a brew- ing yeast from China and the strain NCYC 396 considered as a type strain of $\mathrm{S}$. carlsbergensis. These strains are not listed under the lager yeast because they clearly differ from them in the organization of the RDNI and HIS4 genes as is detailed below. 


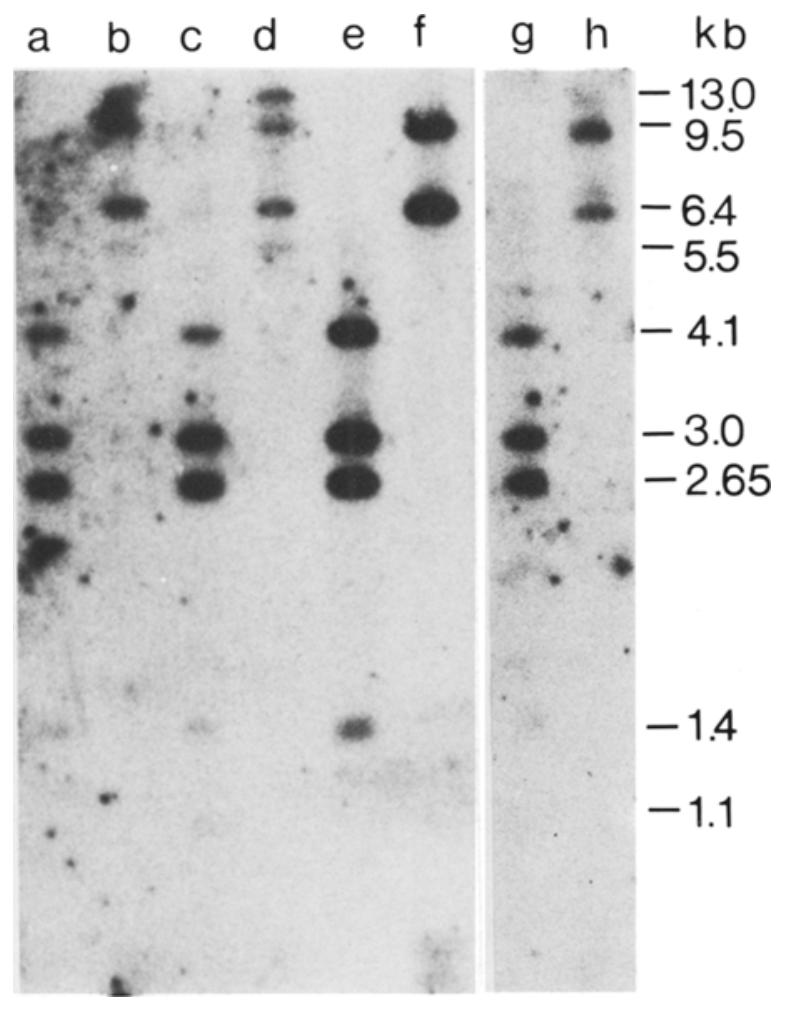

\begin{tabular}{lllll}
\hline Lane & $\begin{array}{l}\text { restriction } \\
\text { endonuclease }\end{array}$ & strain & HIS4 bands (kb) & pattern \\
\hline a & EcoRI & lager strain BK1100 & $4.1,3.0,2.65,1.4$ & I and II \\
b & HindIII & lager strain BK1 100 & $13.0,9.5,6.4,5.5$ & I and II \\
c & EcoRI & lager strain BK2237 & $6.2,4.1,3.0,2.65$, & I and II \\
& & & $1.4,1.1$ & \\
d & HindIII & lager strain BK2237 & $13.0,9.5,6.4,5.5$ & I and II \\
e & EcoRI & ale strain BK3300 & $4.1,3.0,2.65,1.4$ & I \\
f & HindIII & ale strain BK3300 & $9.5,6.4$ & I \\
g & EcoRI & S. (carlsbergensis) NCYC396 & $4.1,3.0,2.65,1.4$ & I and II \\
h & HindIII & S. (carlsbergensis) NCYC396 & $13.0,9.5,6.4$ & I and II \\
\hline
\end{tabular}

Figure 5. Autoradiograph of restriction endonuclease fragment patterns of S. (carlsbergensis) NCYC396 compared with two lager strains and one ale strain. Lanes $\mathbf{a}, \mathbf{c}, \mathbf{e}$ and $\mathbf{g}$ contain EcoRI digested DNA while lanes $\mathbf{b}, \mathbf{d}, \mathbf{f}$ and $\mathbf{h}$ are loaded with HindIII digested DNA. Approximately $1 \mu \mathrm{g}$ of DNA has been applied in each slot. Molecular hybridization of the radioactively labelled $H I S 4$ containing plasmid has been performed at high stringency of hybridization (68 ${ }^{\circ} \mathrm{C}$ with $3 \times \mathrm{SSC}$ ). Washing was done at low salt condition at the same temperature. ${ }^{*}=$ hybridizing with low intensity

3.2. Molecular analysis of the rDNA genes corresponding to the RDN1 gene in Saccharomyces cerevisiae

The EcoRI and HindIII restriction site maps of the two previously identified forms of the $R D N 1$ gene are given in Figure $1 \mathrm{~A}(5,20,23,24)$. Also indicated are the regions encoding the different cytosolic ribosomal RNA molecules and 

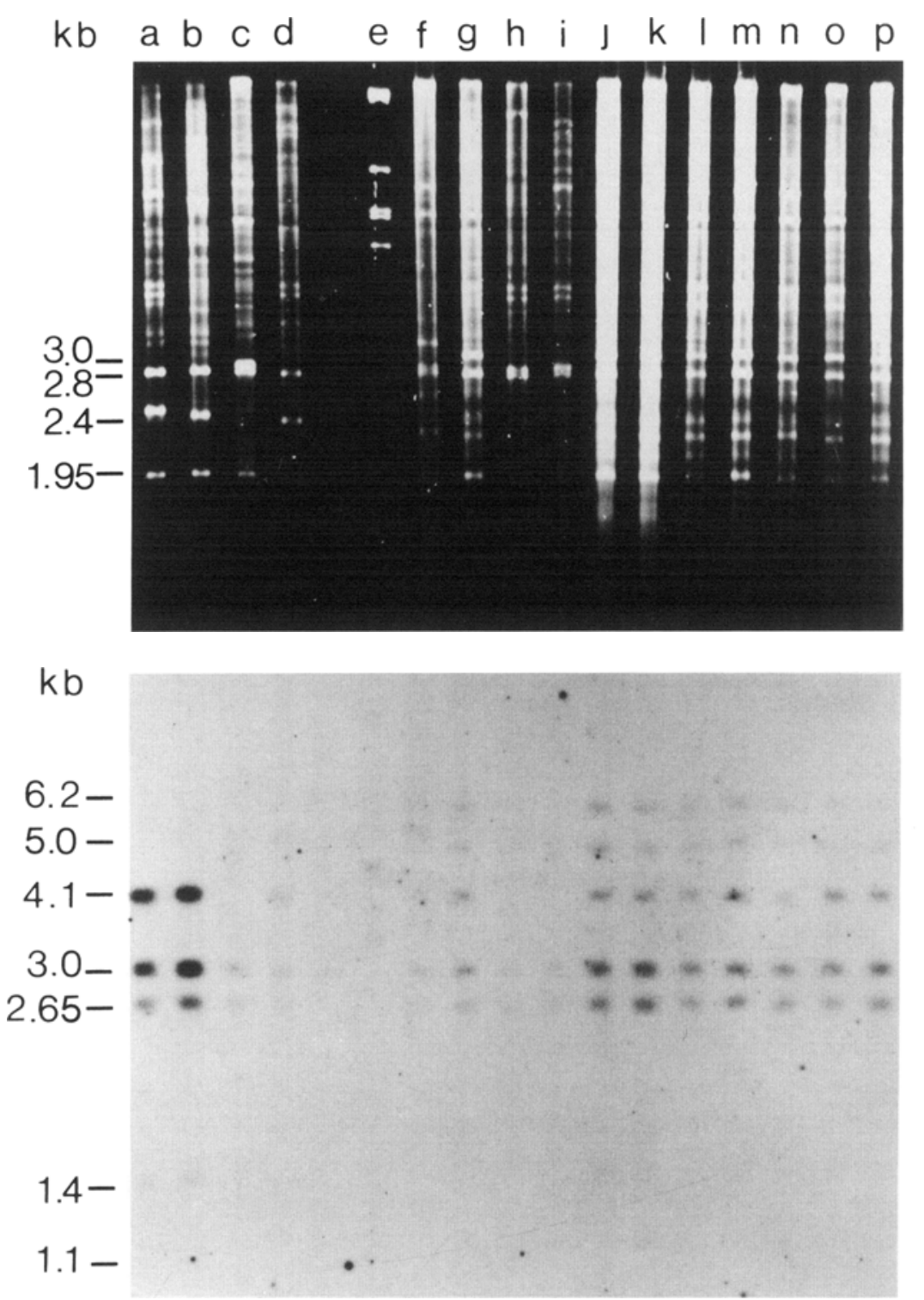

the spacers separating them. As an example for the restriction endonuclease fragment pattern of form $I$ the one for Saccharomyces ellipsoideus (BK4479) is presented (Figure IB). Of the seven EcoRI fragments the five largest are easily identified (lane a). HindIII produces only two fragments as seen in lane $b$ of Figure 1B. Form II of the $R D N I$ gene, here represented by the Carlsberg lager strain (BK2246), yields the same HindIII restriction endonuclease fragment pattern as form $I$ but is distinguished from the latter by the absence of the EcoRI restriction site sepa- rating the $E$ and $B$ fragments. This leads to a fragment $X^{\prime}$ with a size of about $3 \mathrm{~kb}$ (lane $\mathrm{c}$, Figure 1B).

In the course of this investigation a third form of the RDN1 gene has been discovered. As an example for the gene the restriction endonuclease fragment patterns of the DNA from Saccharomyces bayanus (BK4411) are given in Figure 1B. Form III is distinguishable from forms I and II in both the EcoRI and the HindIII patterns. In the EcoRI pattern fragment $\mathrm{A}(2.8$ $\mathrm{kb}$ ) and a fragment corresponding to $X^{\prime}$ but 


\begin{tabular}{|c|c|c|c|c|}
\hline Lane & strain & RDNI Form & HIS4 bands & pattern \\
\hline a & S. spec. C81-1471 & I & $4.1,3.0,2.65,1.4$ & I \\
\hline b & S. cerevisiae $C 81-1483$ & I & $4.1,3.0,2.65,1.4$ & I \\
\hline c & S. uvarum $C 81-1511$ & III & $5.0,3.0,2.65$ & III \\
\hline d & brewing strain C81-1537 & I & $4.1,3.0,2.65,1.4$ & I \\
\hline e & bacteriophage $\lambda$ DNA & & & \\
\hline f & lager strain BK4515 & III & $6.2,4.1,3.0,2.65$ & I and Il \\
\hline $\mathbf{g}$ & Carlsberg lager strain BK2246 & II & $\begin{array}{l}6.2,5.0,4.1,3.0 \\
2.65,1.4,1.1\end{array}$ & I and Il \\
\hline $\mathbf{h}$ & S. bayanus NCYC374 & III & $3.0,2.65$ & \\
\hline i & S. pastorianus NCYC392 & III & $3.0,2.65$ & \\
\hline $\mathbf{j}$ & Carlsberg lager strain BK2246 & II & $\begin{array}{l}6.2,5.0,4.1,3.0 \\
2.65,1.4,1.1\end{array}$ & $\mathrm{I}$ and $\mathrm{I}$ \\
\hline $\mathbf{k}$ & lager strain BK1103 & II & $"$ & $\mathrm{I}$ and $\mathrm{Il}$ \\
\hline 1 & lager strain BK1112 & II & $"$ & $\mathrm{I}$ and $\mathrm{II}$ \\
\hline $\mathbf{m}$ & lager strain BK 1115 & II & $"$ & I and II \\
\hline n & lager strain BK1116 & II & " & $\mathrm{I}$ and II \\
\hline o & lager strain BK2229 & II & $"$ & I and II \\
\hline $\mathbf{p}$ & lager strain BK2236 & II & $"$ & $\mathrm{I}$ and $\mathrm{I}$ \\
\hline
\end{tabular}

Figure 6. EcoRI restriction endonuclease fragment patterns of the genes RDNI (Figure 6A) and HIS4 (Figure 6B). 0.5 to $2 \mu \mathrm{g}$ of EcoRI digested DNA has been loaded in each slot. The major $R D N I$ gene fragments are visible in Figure $6 \mathrm{~A}$. Molecular hybridization of the radioactively labelled HIS4 probe has been performed at $58^{\circ} \mathrm{C}$ with $3 \times \mathrm{SSC}$. Washing of the filter bound DNA was done at low salt conditions $\left(0.1 \times \mathrm{SSC}\right.$ at $\left.58^{\circ} \mathrm{C}\right)$.

smaller (also about $2.8 \mathrm{~kb}$ ) appear as a double band. In addition, fragments $\mathrm{C}(1.95 \mathrm{~kb})$ and fragment $\mathrm{D}(0.66 \mathrm{~kb})$ are present (Figure $1 \mathrm{~B}$, lane c). HindIII cuts this $R D N 1$ gene into three fragments, with sizes of $6.4,1.45$ and $1.15 \mathrm{~kb}$, respectively, (Figure 1B, lane c).

All 30 lager strains (Saccharomyces carlsbergensis) had form II of the RDNl gene (Table I). Of the 11 ale strains (Saccharomyces cerevisiae) all had form II with the exception of strain BK3331, which contained form I (Table II). Form III of the RDNI gene was characteristic for Saccharomyces bayanus, $S$. pastorianus, $S$. uvarum, a brewing strain from China and strain NCYC 396 considered as a type strain of S. carlsbergensis (Table III). All other species studied except one contained form I.

Saccharomyces fermentati (NCYC 161) revealed a very different form of the $R D N I$ gene. In order to compare this additional form of the $R D N 1$ gene with form I it was probed with both pYlrA12 plasmid containing the entire $R D N I$ gene of form I (S. cerevisiae) and a plasmid derivative thereof containing $100 \mathrm{bp}$ of EcoRI fragment $G$ and 900 bp of fragment $C$ thus covering about half of the region transcribed into the $18 \mathrm{~S}$ ribosomal RNA (Figure 1A).

This latter plasmid ("18S"pY1rA12) originated as a recombinant product from the original plasmid which contained as insert a fragment bordered on one side by a portion of the $G$ region and on the other by a full $G$ region plus a 900 bp segment of the $C$ region. A recombination event in the duplicated segments has deleted all of the $R D N 1$ gene except the 1000 bp retained in the "18S"pY1rA12 plasmid.

Figure 2 shows that the plasmid containing the $18 \mathrm{~S}$ region hybridizes in agreement with the expectation to the EcoRI fragment $\mathrm{C}(1.95 \mathrm{~kb})$ of the RDNI gene (form I) and to both HindIII fragments (lanes $\mathrm{c}$ and $\mathrm{d}$ ). In S. fermentati the $18 \mathrm{~S}$ region probe hybridizes to a $3.4 \mathrm{~kb}$ EcoRI fragment instead of the $1.95 \mathrm{~kb}$ fragment (Figure 2, lane i). The plasmid containing the entire $R D N I$ gene recognizes in addition the EcoRI fragment $\mathrm{C}$ of $2.8 \mathrm{~kb}$ (Figure 2, lane $\mathrm{k}$ ). Both probes hybridize to a single HindIII generated fragment about $9 \mathrm{~kb}$ in size (Figure 2 , lanes $\mathrm{j}$ and $\mathrm{l}$ ), revealing that the entire $R D N 1$ gene of S. fermentati contains a single HindIII restriction site. The restriction endonuclease fragment patterns of $\mathrm{S}$. fermentati presented in Figure 2 are the same as those de- 


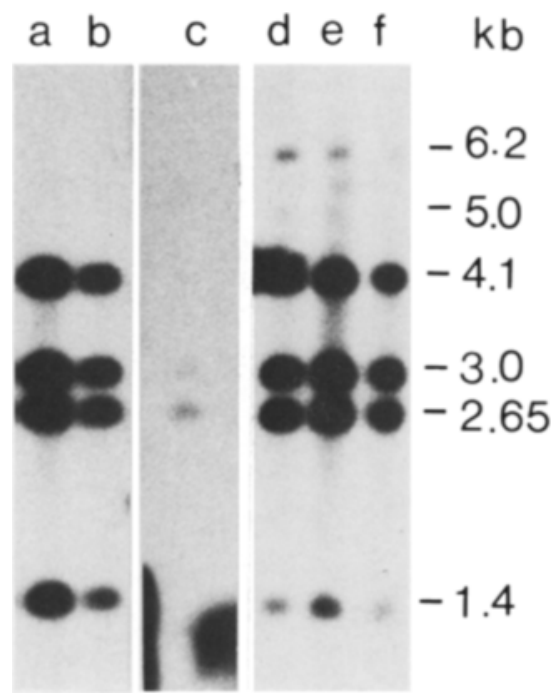

\begin{tabular}{lllc}
\hline Lane & strain & HIS4 bands $(\mathrm{kb})$ & pattern \\
\hline a & S. spec. BK4525 & $4.1,3.0,2.65,1.4$ & I \\
b & S. spec. BK4526 & $4.1,3.0,2.65,1.4$ & I \\
c & S. uvarum C81-1510 & $3.0,2.65$ & \\
d & Carlsberg lager strain BK2246 & $6.2,4.1,3.0,2.65,1.4$ & I and II \\
e & Hybrid strain C82-CG625 & $6.2,4.1,3.0,2.65,1.4$ & I and II \\
f & lager strain C82-FP32 & $6.2,4.1,3.0,2.65,1.4$ & I and II \\
\hline
\end{tabular}

Figure 7. Comparison of EcoRI restriction endonuclease HIS4 fragments of six Saccharomyces strains. Approximately $2 \mu \mathrm{g}$ of EcoRI digested DNA have been loaded in each slot. $1 \mu \mathrm{g}$ of the HIS4 containing plasmid was labelled with $6 \times 10^{7} \mathrm{cpm}$ of $\left[x^{32} \mathrm{P}\right] \mathrm{dATP}$. The molecular hybridization of the probe and washing of the filter were performed at $62{ }^{\circ} \mathrm{C}$ with $3 \times \mathrm{SSC}$. The $\mathrm{S}$. uvarum strain $\mathrm{C} 81-1510$ shows low homology to the probe compared to the other five strains.

scribed for S. rosei (34).

During a microbiological analysis of a production sample of the Carlsberg lager strain BK2246 an aberrant colony was found and cultured (C82FP33). To determine whether the colony was a mutant of the lager strain or a wild yeast colony, the DNAs from the two strains were compared by restriction analysis and molecular hybridization to the $R D N I$ gene probe. In Figure 3, lanes a, $\mathrm{b}$ and $\mathrm{g}, \mathrm{h}$, are shown the fluorescing bands of the ethidium bromide stained fragments from the endonuclease digested DNA of the Carlsberg lager strain (lane a: EcoRI, lane b: HindIII) and of the aberrant strain (lane $\mathrm{g}$ : EcoRI and lane h: HindIII). The strongly fluorescing bands originate from restriction fragments present in multiple copies and they produce quite dissimilar patterns in the two strains. Such sequence divergence cannot be obtained by a single mutational event. The autoradiographs in lanes $c$ - $f$ identify the fluorescing bands containing DNA fragments that can hybridize to the radioactively labelled RDNI gene probe. The Carlsberg lager strain BK2246 (lanes $c$ and d) gives the band patterns characteristic for the RDNI gene form II, while in the wild yeast different DNA fragments are identified by the $R D N 1$ probe (lanes e and $\mathrm{f}$ ). The probe pY1rA12 hybridizes to two EcoRI fragments with a size of $3.9 \mathrm{~kb}$ and $3.0 \mathrm{~kb}$ (lane e) and to a single HindIII fragment band with a size larger than $20 \mathrm{~kb}$ (lane f). Thus the rDNA gene of the contaminant was not cut by HindIII. While the EcoRI and HindIII restriction fragment patterns of this contaminant superficially look similar to those of S. fermentati (Figure 2, k and l) measurement of the RDNI fragment sizes reveal very different genotypes in the two strains. 


\subsection{Molecular analysis of the HIS4 region in Saccharomyces strains}

With regard to the HIS4 region two variants of chromosome III have so far been identified in the genus Saccharomyces (17). Laboratory strains of Saccharomyces cerevisiae contain a chromosome III which upon probing with the HIS4 containing plasmid pC503 (11) is recognized by four EcoRI restriction fragments with sizes of $4.1,3.0,2.65$, and $1.4 \mathrm{~kb}$. The pattern of this chromosome is designated as I and corresponds to a pattern of six HindIII generated fragments with sizes of $9.5,6.4,0.69,0.62,0.46$ and $0.39 \mathrm{~kb}$. The Carlsberg lager strain contains a chromosome with pattern I and a homeologous chromosome which upon endonuclease digestion generates pattern II consisting of EcoRI fragments with sizes of $6.2,5.0,3.0,2.65,1.1 \mathrm{~kb}$ and two HindIII fragments with sizes of 13.0 and $5.5 \mathrm{~kb}$. All these fragments hybridize only weakly with the HIS4 containing plasmid indicating extensive sequence differences between the "cerevisiae" HIS4 region and that in the homeologous chromosome.

Of the strains analysed in Figure 4, S. italicus (lanes $g$ and $h$ ) has pattern I, the German lager strain BK1101 has pattern II (lanes $\mathrm{c}$ and $\mathrm{h}$ ) while the Carlsberg lager strain BK2246 has a summation of patterns I and II and thus contains both homeologous chromosomes (lanes a and i). The difference in the hybridization intensity of the fragments originating from the two chromosomes III in the lager yeast is clearly illustrated in lane a. A drastic difference in hybridization intensity is also noted between fragments of pattern I (lanes $g$ and $h$ ) and those of pattern II in the German lager strain (lanes $c$ and d), the latter hybridizing with low efficiency. Strain NCYC 396 considered as a type strain of S. carlsbergensis reveals the combination of patterns I and II when EcoRI or HindIII digested DNA is probed with the radioactive plasmid (lanes $\mathrm{e}$ and f). Probably the strain is similar to the tested lager yeasts, but it was consistently observed that the probe hybridized less intensely to the restriction fragments of the NCYC 396 strain than to those of lager strains (cf. lane $i$ with lane f).

At high stringency of hybridization $\left(68{ }^{\circ} \mathrm{C}\right.$, $3 \times \mathrm{SSC}$ ) the fragments diagnostic for pattern II of the HIS4 region in strain NCYC $396 \mathrm{~S}$. carls- bergensis and the lager strain hybridize with weak intensity (Figure 5). This is visible for the 6.2 and $1.4 \mathrm{~kb}$ EcoRI fragment band as well as for the 13.0 and $5.5 \mathrm{~kb}$ HindIII fragment bands. The absence of a $4.1 \mathrm{~kb}$ EcoRI fragment in pattern II results in a less intense band than that shown by the pattern I allele present in the ale strain BK3300 (Figure 5, lane e).

In Figure 6 are shown the fluorograph of the ethidium bromide stained fragments of the EcoRI digested DNA (Figure 6A) and the autoradiograph after transfer of the fragments to a filter and their hybridization to the radioactively labelled HIS4 probe (Figure 6B). In this experiment the chromosomes displaying pattern I of HIS4 in the Saccharomyces strains C81-1471 and C81-1483 (lane $a$ and $b$ ) show stronger homology to the probe than those in the lager strains (lanes $j$ through p).

Three strains show weaker homology of their HIS4 regions to the probe than all the other strains (Figure 6 lanes c,h,i). These are S. uvarum C81-1511, S. pastorianus NCYC 392 (BK4516) and S. bayanus NCYC 374 (BK4505) which only give detectable hybridization to the 2.65, 3.0 and $5.0 \mathrm{~kb}$ fragments containing the HIS4 region. At higher stringency $\left(62{ }^{\circ} \mathrm{C} 3 \times \mathrm{SSC}\right)$ a prominent difference in hybridization intensity appears between the $2.65 \mathrm{~kb}$ and $3.0 \mathrm{~kb}$ fragments of $\mathrm{S}$. uvarum strain C81-1510, whereas such a difference is not observed in the other Saccharomyces strains (Figure 7). The Saccharomyces strains, BK4525 and BK4526, contain pattern I of $H I S 4$, while the Carlsberg lager strain BK2246, the hybrid lager strain C82CG625 and the Finnish lager strain C82-FP32 carry both patterns I and II of HIS4.

At low stringency $\left(58^{\circ} \mathrm{C}\right)$ six to seven genotypes can be distinguished with the HIS4 probe. The DNA of the eight strains has been digested with restriction endonucleases EcoRI, HindIII, PstI, PvuII and SalI (Figure 8). Looking at the patterns obtained with the restriction endonuclease HindIII (lanes a to $h$ ) six genotypes can be distinguished: (a) Pattern I + II from the Carlsberg lager strain. (b) The German lager strain with pattern II. (c) This lane contains the DNA of the strain considered a type strain of S. carlsbergensis, but was not cut in the particular experiment. Its pattern I + II has been presented in 


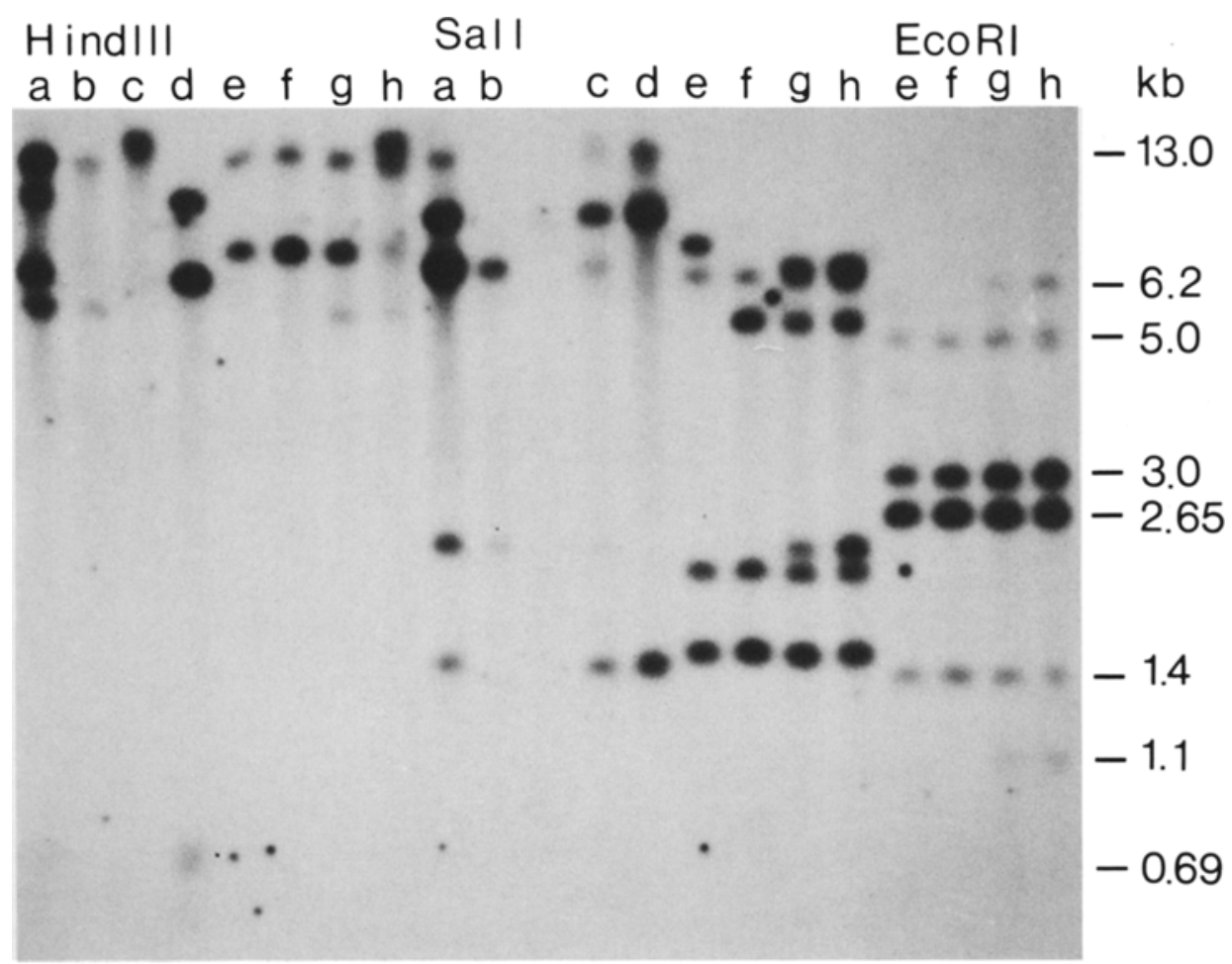

Pst I

Pvull

\section{EcoRI}

$a b c d e f g h a b \quad c d e f g h a b c d k b$

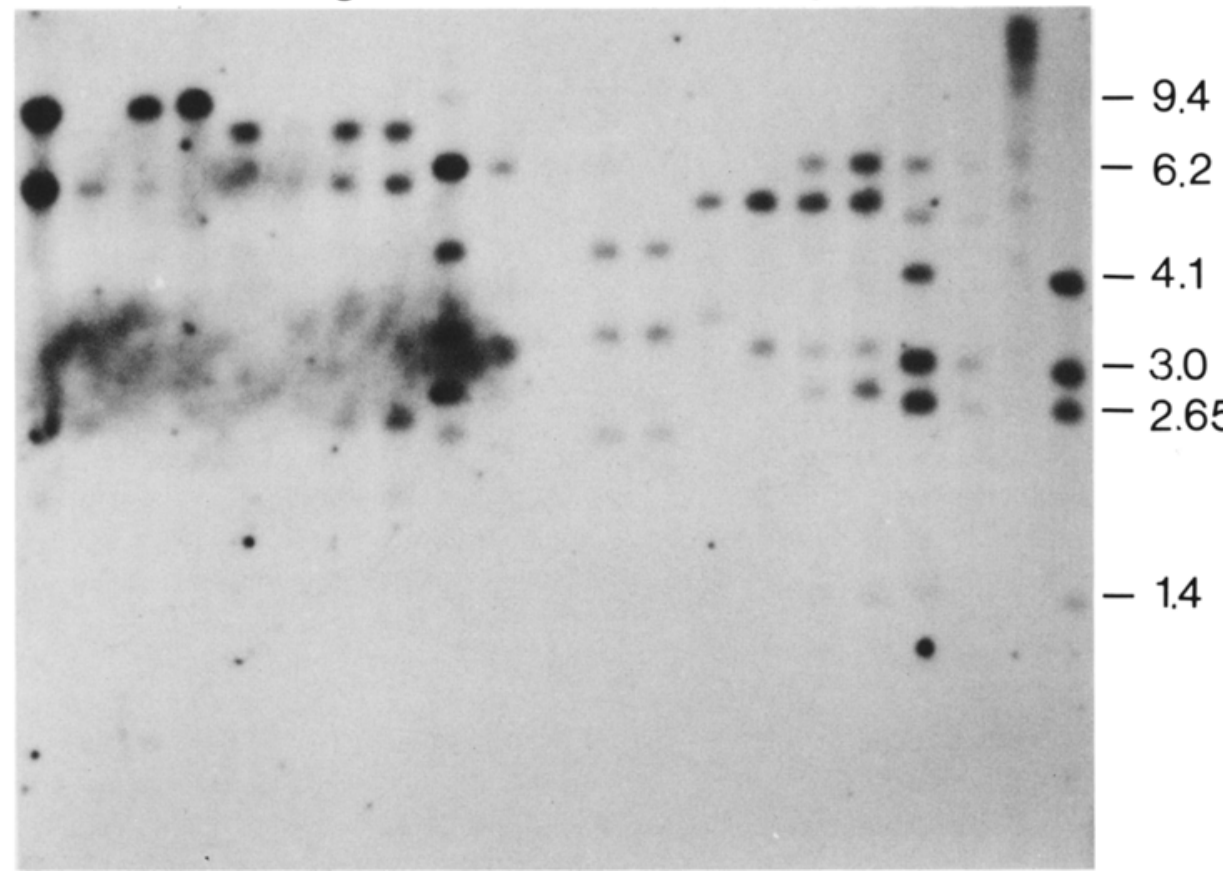




\begin{tabular}{|c|c|c|c|c|c|c|}
\hline \multirow{2}{*}{\multicolumn{2}{|c|}{ Strain, pattern }} & \multicolumn{5}{|c|}{ Restriction fragment sizes in $\mathrm{kb}$} \\
\hline & & EcoRI & HindIII & Pvull & PstI & Sall \\
\hline a & $\begin{array}{l}\text { Carlsberg lager strain } \\
\text { BK } 2246 \text { pattern I } \\
\text { and II }\end{array}$ & $\begin{array}{l}6.2,5.0,4.1 \\
3.0,2.65,1.4 \\
1.1\end{array}$ & $\begin{array}{l}13.0,9.0,6.4 \\
5.5,0.69,0.62\end{array}$ & $\begin{array}{l}9.4,6.2,4.9 \\
3.5,2.75,1.4\end{array}$ & $9.4,6.0,2,5$ & $\begin{array}{l}13.0,9.4,6.7, \\
2.3,1.5\end{array}$ \\
\hline b & $\begin{array}{l}\text { German lager strain } \\
\text { BK } 1101 \text { pattern II }\end{array}$ & $\begin{array}{l}6.2,5.0,3.0 \\
2.65\end{array}$ & $13.0,5.5$ & $6.2,3.5$ & $6.0,2.5$ & $6.7,2.3$ \\
\hline c & $\begin{array}{l}\text { S. (carlsbergensis) } \\
\text { NCYC396 } \\
\text { pattern I and Ila }\end{array}$ & $\begin{array}{l}6.2,5.0,4.1 \\
3.0,2.65\end{array}$ & (cf. Fig. 4 and 5) & $\begin{array}{l}9.4,6.2,4.9 \\
3.5,2.5\end{array}$ & $9.4,6.0$ & $\begin{array}{l}13.0,9.4,6.7, \\
2.3,1.5\end{array}$ \\
\hline d & $\begin{array}{l}\text { S. cerevisiae } \\
\text { C81-1483 pattern I }\end{array}$ & $\begin{array}{l}4.1,3.0,2.65 \\
1.4\end{array}$ & $\begin{array}{l}9.5,6.4,0.69 \\
0.62\end{array}$ & $\begin{array}{l}9.4,4.9,3.5 \\
2.5\end{array}$ & 9.4 & $13.0,9.4,1.5$ \\
\hline e & $\begin{array}{l}\text { S. uvarum } \\
\text { C81-1510 pattern IIIa }\end{array}$ & $\begin{array}{l}5.0,3.0,2.65 \\
1.4\end{array}$ & $13.0,7.5$ & $\begin{array}{l}5.9,3.8,1.4 \\
1.3\end{array}$ & 8.0 & $\begin{array}{l}7.5,6.4,2.1 \\
1.6\end{array}$ \\
\hline f & $\begin{array}{l}\text { S. uvarum } \\
\text { C81-1511 pattern III }\end{array}$ & $\begin{array}{l}5.0,3.0,2.65 \\
1.4\end{array}$ & $13.0,7.5$ & $\begin{array}{l}5.9,3.4,1.4 \\
1.3\end{array}$ & 8.0 & $\begin{array}{l}6.4,5.5,2.1 \\
1.6\end{array}$ \\
\hline $\mathbf{g}$ & $\begin{array}{l}\text { S. pastorianus } \\
\text { NCYC } 392 \text { pattern II } \\
\text { and III }\end{array}$ & $\begin{array}{l}6.2,5.0,3.0 \\
2.65,1.4,1.1\end{array}$ & $13.0,7.5,5.5$ & $\begin{array}{l}6.2,5.9,3.4 \\
2.75,1.4,1.2\end{array}$ & $8.0,6.0,2.5$ & $\begin{array}{l}6.7,6.4,5.5 \\
2.3,2.1,1.6\end{array}$ \\
\hline $\mathbf{h}$ & $\begin{array}{l}\text { S. bayanus } \\
\text { NCYC } 374 \text { Pattern II } \\
\text { and III }\end{array}$ & $\begin{array}{l}6.2,5.0,3.0 \\
2.65,1.4,1.1\end{array}$ & $13.0,7.5,5.5$ & $\begin{array}{l}6.2,5.9,3.4 \\
2.75,1.4,1.2\end{array}$ & $8.0,6.0,2.5$ & $\begin{array}{l}6.7,6.4,5.5 \\
2.3,2.1,1.6\end{array}$ \\
\hline
\end{tabular}

4 Figure 8. Structural differences in the HIS4 region of eight Saccharomyces strains revealed by restriction endonuclease analysis and molecular hybridization to the radioactively labelled plasmid pC503 containing the HIS4 region (11). Each of the isolated DNAs have been digested by five restriction enzymes.

Four of the strains are heterozygous for HIS4 ( $\mathrm{a}, \mathrm{c}, \mathrm{g}$ and $\mathbf{h})$, the others seem to be homozygous for either pattern I, II or III (b, d, e and $\mathbf{f}$.

Figure 4, lane f. (d) The typical pattern I of S. cerevisiae. (e) and (f) The patterns of the $S$. uvarum accessions contain a $13 \mathrm{~kb}$ and a more intense hybridizing $7.5 \mathrm{~kb}$ fragment designated as pattern III. $(\mathrm{g})$ and $(\mathrm{h})$ The patterns are from $\mathrm{S}$. pastorianus and $S$. bayanus and represent a summation of pattern II $(=b)$ and III $(=f)$. (The DNA in lane $h$ was only partially cut.)

The Sall patterns (lanes a - h) permit the distinction of seven genotypes. (a) The Carlsberg lager strain pattern I + II reveals 5 fragments, which represent the summation of the fragments present in (b) (= pattern II) and (d) (= pattern I). (c) The strain considered as a type strain for $\mathrm{S}$. carlsbergensis contains all the fragments presentin the lager yeast (a) but there is a drastic difference between the two strains in hybridization intensity. (e) and (f) The restriction fragment pattern of the S. uvarum strain (C81-1510) is distinguished from the S. uvarum strain (C81-1511) by having a $7.5 \mathrm{~kb}$ fragment instead of a $5.5 \mathrm{~kb}$ fragment. (g) and (h) S. pastorianus and $\mathrm{S}$. bayanus have patterns consisting of the summation of those in (b) and (f) i.e. pattern II + III.

The PstI and PvulI fragment patterns of the 8 strains confirm the existence of seven genotypes as detailed in the legend to Figure 8. The EcoRI restricted DNA of S. uvarum gives the pattern III for this endonuclease (lanes $e$ and $\mathrm{f}$ ). It consists of 4 fragments with sizes of $5.0,3.0,2.65$ and $1.4 \mathrm{~kb}$. The EcoRI fragment patterns of $S$. pastorianus and $S$. bayanus (lanes $g$ and $h$ ) are in agreement with the summation of patterns II (b) and III (f).

\section{DISCUSSION}

As summarized in Figure 9 the EcoRI restriction fragments of the $R D N I$ gene encoding the cytosolic ribosomal RNA molecules allow to distinguish three forms. Form III is distinct from the previously mapped forms I and II (cf. Figure 
1A) by having a fragment of $2.9 \mathrm{~kb}$. Most likely,this fragment has originated from the $X$ ' fragment of form II by deletion of a segment in the 3' spacer region. Further work is required to demonstrate the presence of the EcoRI F and G fragments. Form III is also distinguished in the HindIII pattern by the presence of a third HindIII site in the gene. Form III allows to identify $S$. bayanus, $S$. pastorianus and $S$. uvarum which all are homozygous for this form.

By virtue of its ability to ferment glucose, sucrose, maltose and raffinose (33) and its inability to utilize galactose, $S$. fermentati superficially resembles $\mathrm{S}$. bayanus. It is considered, however, to be most closely related to $S$. rosei (33). The $R D N 1$ of S. fermentati (3.2 and Figure 2) was found to have an organization which corresponds to that determined by VERBEET et al. (34) for $\mathrm{S}$. rosei. This $R D N 1$ gene is about $500 \mathrm{bp}$ smaller than forms I and III and characterized by having a single HindIII site. The "18S" ribosomal RNA probe used in the present investigation and the similar probe used by VERBEET et al. hybridizes in both strains to a $3.4 \mathrm{~kb}$ EcoRI restriction fragment indicating a similar overall organization. The probe with the total form II of $R D N I$ hybridizes to $\mathrm{S}$. fermentati EcoRI fragments of $3.4 \mathrm{~kb}$ and $2.8 \mathrm{~kb}$. Fragments of the same size in $\mathrm{S}$. rosei hybridize to the probe pMY 60 containing a form I RDNI gene (34). In the latter paper a detailed comparison is made between form I and the S. rosei rDNA unit by heteroduplex mapping and partial nucleotide sequencing. The large difference between the $S$. rosei and the form I rDNA is entirely due to less sequence homology in the spacer regions. The analysis of the ribosomal RNA genes is in agreement with the observations by YARROW and NAKASE (38) that S. rosei and S. fermentati have the same sero-type composition and cell wall structures. They thus belong to the same species and are furthermore closely related to Torulaspora delbrueckii (38).

The chromosomal region containing the HIS4 gene occurred in three different allelic forms, designated as patterns I, II and III. With one exception the lager strains (Table I) contained chromosomes with patterns I and II but were homozygous for form II of the RDN1. The exception is the strain formerly used by the Bavarian brewery Pschorr which is homozygous for the HIS4 pattern II. A hybrid between two spore clones of the Carlsberg lager strain BK2246 with such a homozygous pattern II has been produced and was recently successfully employed in production of beer $(10,25)$.

With the exception of strain BK3331, ale strains (Table II) contained form II of the RDN] gene and were homozygous for pattern I of the HIS4 region. The ale strain BK3331 contained form I of the RDN1 gene. Progeny analysis of the strains C82-FP23 and C82-FP25 are required to determine the nature of the populations observed in these two accessions.

Most useful is the combination of the RDNI and HIS4 analysis to distinguish the strains listed in Table III. S. odessa, S. diastaticus, S. ellipsoideus, $S$. italicus, bakers yeast and a beer contaminant were homozygous for form I of RDNI and pattern I of HIS4. This genotype was also found in a strain isolated from Trappiste beer (C81-1537). S. bayanus, S. pastorianus and S. uvarum were characterized by homozygosity for the $R D N 1$ gene form III and the presence of pattern II of the HIS4 gene. S. pastorianus and S. bayanus were heterozygous for patterns III and II of HIS4, while the two accessions of S. uvarum were homozygous for pattern III.

Previous studies on molecular cross hybridization of DNA from S. uvarum and S. bayanus have shown $95 \%$ homology between the DNA of the two species (28) while only $40 \%$ is found between $S$. uvarum and $S$. cerevisiae (1). $S$. uvarum, $S$. bayanus and $S$. pastorianus are thus closely related and taxonomical evaluation based on the capacity to ferment melibiose is misleading in this case.

The ribosomal RNA gene form III is also present in strain NCYC 396 considered as a type strain of S. carlsbergensis, but combined with pattern I and II of the HIS4 region. It was noted that the HIS4 region pattern II fragments of this strain hybridize less intensely with the $S$. cerevisiae probe than the corresponding fragments from the lager yeast strains listed in Table I. This type strain differs thus from $\mathrm{S}$. uvarum in the HIS4 region of chromosome III, it is similar to $\mathrm{S}$. uvarum in the $R D N 1$ region of chromosome XII but differs in that respect from the lager yeast strains. All three groups of strains ferment 


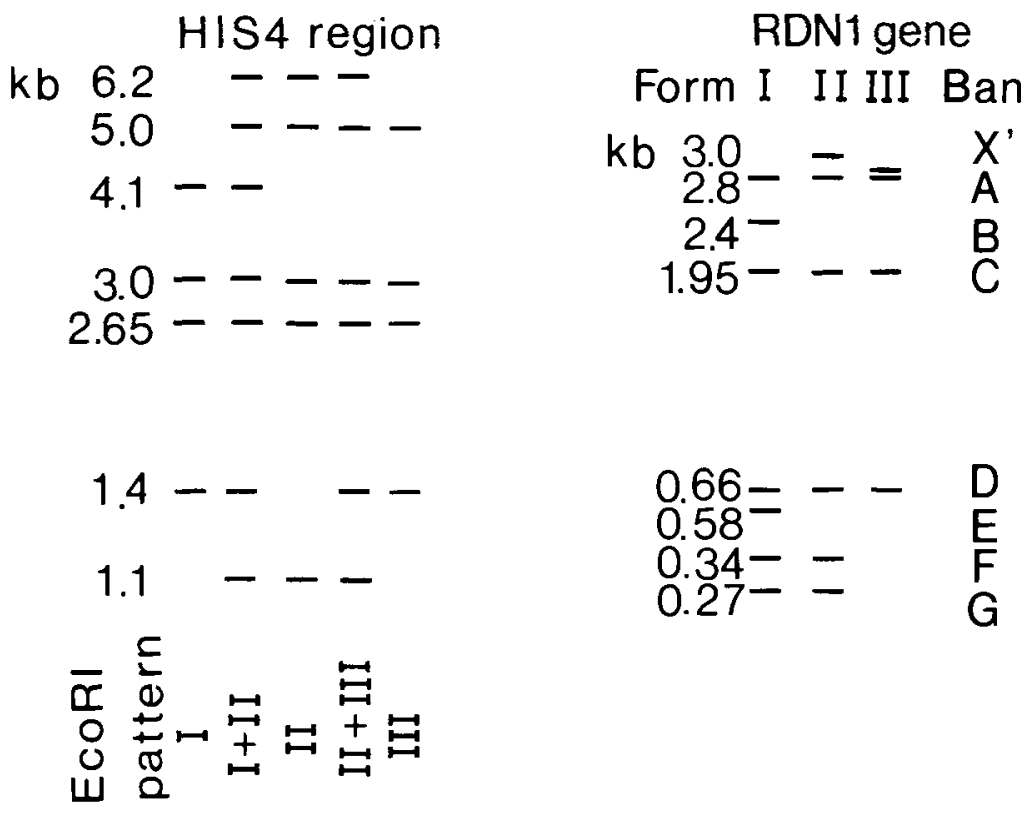

Figure 9. Diagnostic key to EcoRI restriction endonuclease fragment patterns for the $H I S 4$ region and the $R D N /$ gene. Fragment sizes are in $\mathrm{kb}$ (thousands of base pairs).

melibiose. Further studies which include additional genes and properties are necessary to evaluate the taxonomic status of strain NCYC 396 and the strain with the same genotype obtained from China (BK4515).

\section{ACKNOWLEDGEMENTS}

The author would like to thank dr. S. HOLMBERG for providing the plasmid pC503 and dr. T. Petes for the plasmid pYlrA12. The two S. uvarum strains were kindly sent by dr. P. PHILIPPSEN. The author is indebted to Professor D. vON WetTSTEIN for initiating this study and Mr. L. Pagh-Rasmussen, General Manager, International Technical Services, United Breweries for procuring the brewing strains. For valuable discussions and help I would like to thank Research Manager B. Ahrenst-Larsen, dr. B.S. EnevoldSEN, cand.scient. C. GJermansen, dr. M.C. Kielland-Brandt, dr. T. NilsSon-Tillgren and dr.med.vet. P. SigsgaARD.

\section{REFERENCES}

1. Bicknell, J.N. \& H.C. Douglas: Nucleic acid homologies among species of Saccharomyces. J. Bacteriol. 101, 505-512 (1970)
2. Buckholz, R.G. \& B.G. AdAms: Induction and genetics of two $\alpha$-galactosidase activities in Saccharomyces cerevisiae. Mol. Gen. Genet. 182, $77-81(1981)$

3. Cameron, J.R., P. Philippsen \& R.W. Davis: Analysis of chromosomal integration and deletions of yeast plasmids. Nucl. Acids Res. 4, 14291448 (1977)

4. Carlson, M. \& D. Botstein: Organization of the SUC gene family in Saccharomyces. Mol. Cell. Biol. 3, 351-359 (1983)

5. Cramer, J.H., F.W. Farrelly \& R.H. Rownd: Restriction endonuclease analysis of ribosomal DNA from Saccharomyces cerevisiae. Mol. Gen. Genet. 148, 233-241 (1976)

6. Delihas, N. \& J. Andersen: Generalized structures of the 5S ribosomal RNAs. Nucl. Acids Res. 10, 7323-7344 (1982)

7. DENHARDT, D.T: A membrane-filter technique for the detection of complementary DNA. Biochem. Biophys. Res. Comm. 23, 641-646 (1966)

8. Donhauser, S., H. Rirter \& J. Schmitt: Genetische Variabilität der Alkoholdehydrogenasen bei Saccharomyces. Proc. 18th Europ. Brewery Conv. Congr. Copenhagen. 187-196 (1981)

9. Erdmann, V.A., E. Huysmans, A. VanderBERGHE \& R. DE WACHTER: Collection of published $5 \mathrm{~S}$ and 5.8S ribosomal sequences. Nucl. Acids Res. 11, r105-r123(1983) 
10. Guermansen, C. \& P. Sigsgaard: Construction of a hybrid brewing strain of Saccharomyces carlsbergensis by mating of meiotic segregants. Carlsberg Res. Commun. 46, 1-11 (1981)

11. Holmberg, S., J.G.L. Petersen, T. NilssonTillgren \& M. C. Kielland-Brandt: Molecular characterization of a Saccharomyces plasmid containing the HIS4 gene. Carlsberg Res. Commun. 44, 269-282 (1979)

12. Holmberg, S.: Genetic differences between Saccharomyces carlsbergensis and S. cerevisiae II. Restriction endonuclease analysis of genes in chromosome III. Carlsberg Res. Commun. 47, 233-244 (1982)

13. Holmes, D.S. \& M. Quigley: A rapid boiling method for the preparation of bacterial plasmids. Anal. Biochem. 114, 193-197 (1981)

14. JefFREYS, A.J. \& R.A. FlAVELL: A physical map of the DNA regions flanking the rabbit $\beta$-globin gene. Cell 12, 429-439 (1977)

15. JOHANNSEN, E. \& J.P. VAN DER WALT: Interfertility as basis for the delimitation of Kluyveromyces marxianus. Arch. Microbiol. $118,45-48(1978)$

16. Maniatis T., E. F. Fritsch \& J. SambrooK: Molecular cloning. A laboratory manual. Cold Spring Harbor Laboratory (1982)

17. Nilsson-Tillgren, T., C. Guermansen, M.C. Kielland-Brandt, J.G.L. Petersen \& S. HOLMBERG: Genetic differences between Saccharomyces carlsbergensis and $\mathrm{S}$. cerevisiae. Analysis of chromosome III by single chromosome transfer. Carlsberg Res. Commun. 46, 6576 (1981)

18. Peacock, A.C. \& C.W. Dingman: Molecular weight estimation and separation of ribonucleic acid by electrophoresis in agarose-acrylamide composite gels. Biochemistry 7, 668-674 (1968)

19. Pedersen, M.B.: Fingerprinting of DNA in the identification of yeast. Proc. 19th Europ. Brewery Conv. Congr. London, pp. 457-463 (1983)

20. Petes, T.D., L.M. Hereford \& K.G. Skryabin: Characterization of two types of yeast ribosomal DNA genes. J. Bacteriol. 134, 295-305 (1978)

21. Petes, T.D., S. Smolik-Utlaut \& T. Zamb; Genetic analysis of the repeating ribosomal DNA genes of yeast. In: Molecular Genetics in Yeast. Alfred Benzon Symposium 16. Eds.: D. von Wettstein, J. Friis, M. Kielland-Brandt \& A. Stenderup. Munksgaard. Copenhagen. pp 137$151(1981)$

22. PETES, T.D.: Meiotic mapping of yeast ribosomal deoxyribonucleic acid on chromosome XII. J. Bacteriol. 138, 185-192 (1979)

23. Philippsen, P., R.A. Kramer \& R.W. Davis:
Cloning of the yeast ribosomal DNA repeat unit in SstI and HindIII lambda vectors using genetic and physical size selections. J. Mol. Biol. 123, 371-386 (1978)

24. Philippsen, P., M. Thomas, R.A. Kramer \& R.W. DAVIS: Unique arrangement of coding sequences for $5 \mathrm{~S}, 5.8 \mathrm{~S}, 18 \mathrm{~S}, 25 \mathrm{~S}$ ribosomal RNA in Saccharomyces cerevisiae as determined by R-loop and hybridization analysis. J. Mol. Biol. 123, 287-404 (1978)

25. Price, C.W., G.B. Fuson \& H.J. Phaff: Genome comparison in yeast systematics: Species within the genera Schwanniomyces, Saccharomyces, Debaryomyces and Picia. Microbiol. Rev. 42, 161-193 (1978)

26. Rigby, P.W.J., M. Dieckmann, C. Rhodes \& P. BERG: Labeling deoxyribonucleic acid to high specific activity in vitro by nick translation with DNA polymerase I. J. Mol. Biol. 113, 237-251 (1977)

27. Rosenthal, A.L. \& A. Saifer: Continuous monitoring of fluorogenic substrates $\mathbf{I}$. Kinetic analysis of $\mathrm{N}$-acetyl- $\beta$-D-hexosaminidases. Anal. Biochem. 55, 85-92 (1973)

28. Rosini, G., F. Federici, A.E. Vaughan \& A. MARTINI: Systematics of the species of the genus Saccharomyces associated with the fermentation industry. European J. Appl. Microbiol. Biotechnol. 15, 188-193 (1982)

29. Schweitzer, E., C. MacKechnie \& H.O. HALVORSON: The redundancy of ribosomal and transfer RNA genes in Saccharomyces cerevisiae. J. Mol. Biol. 40, 261-277 (1969)

30. Sherman, F., G.R. Fink \& J.B. Hicks: Methods in Yeast Genetics. Cold Spring Harbor Laboratory, Cold Spring Harbor, N.Y. 11724 . pp 61-64 (1979)

31. Southern, E.M.: Detection of specific sequences among DNA fragments separated by gel electrophoresis. J. Mol. Biol. 98, 503-517 (1975)

32. Torczynski, R., A.P. Bollon \& M. Fuke: The complete nucleotide sequence of the rat $18 \mathrm{~S}$ ribosomal RNA gene and comparison with the respective yeast and frog genes. Nucl. Acids Res. $11,4879-4890$ (1983)

33. VAN DER WALT, J.P.: Genus Saccharomyces. In: The Yeasts, a Taxonomic Study. J. Lodder, ed. North-Holland Publishing Company. Amsterdam London pp. 555-718 (1970)

34. Verbeet, M.Ph., J. Klootwuk, H. van Heerikshuisen, R. Fontijn, E. Vreugdenhil \& R.J. PLANTA: Molecular cloning of the rDNA of Saccharomyces rosei and comparison of its transcription initiation region with that of Sac- 
charomyces carlsbergensis. Gene 23, 53-63 (1983)

35. Wettstein, D. von: Emil Christian Hansen Centennial Lecture. From pure culture to genetic engineering of brewers yeast. Proc. 19th Europ. Brewery Conv. Congr. London, pp. 97-119 (1983)

36. Winge, $\varnothing$. \& O. Laustsen: On 14 new yeast types, produced by hybridization. Compt. Rend. Lab. Carlsberg, Ser. Physiol., 22, 337-352 (1939)
37. Yamazaki, M., S. Goto \& K. Komagiata: Comparison of enzymes from strains of wine yeast and their related yeasts on electrophoresis. $\mathbf{J}$. Inst. Enol. Vitic. Yamanashi Univ. 17, 11-19 (1982)

38. YaRrow, D. \& T. NaKasE: DNA base compositions of the genus Saccharomyces. Antonie van Leeuwenhoek 41, 81-88 (1975) 